\title{
Seating positions and children's risk of dying in motor vehicle crashes
}

\author{
Elisa R Braver, Randy Whitfield, Susan A Ferguson
}

\begin{abstract}
Objectives-To determine the effects of seating position, combined with restraint use and airbag status, on children's risk of dying in crashes.

Methods-Using 1988-95 data from the United States Fatality Analysis Reporting System, risk of death was compared among front and rear seated passengers aged 12 and younger who were involved in fatal crashes for different categories of restraint use and in vehicles with and without passenger airbags.

Results-Restrained children in rear seats had the lowest risk of dying in fatal crashes. Among children seated in the rear, risk of death was reduced $35 \%$ in vehicles without any airbags, $31 \%$ in vehicles equipped only with driver airbags, and $46 \%$ in vehicles with passenger airbags. Both restrained and unrestrained children aged 0-12 were at lower risk of dying in rear seats. Rear seats also afforded additional protection to children aged 5-12 restrained only with lap belts compared with lap/shoulder belted children in front seats. Children were about $10-20 \%$ less likely to die in rear center than in rear outboard positions.

Conclusions-Parents and others who transport children should be strongly encouraged to place infants and children in rear seats whether or not vehicles have airbags. Existing laws requiring restraint use by children should be strengthened and actively enforced.

(Injury Prevention 1998;4:181-187)
\end{abstract}

Keywords: airbags; seat belts; highway safety; seating position

Determining the magnitude of protection afforded by rear seating positions has become more important with the advent of passenger airbags. The combined effects of seating position and restraint use also need to be examined because past research has obtained inconsistent findings concerning whether restrained occupants are safer in rear seats than in the front. Another important question is the relative safety of children using lap/shoulder belts in front seats compared with those using only lap belts in rear seats.

Quality Control Systems Corporation, Crownsville, Maryland $\mathrm{R}$ Whitfield

Correspondence to: Dr Braver (e-mail

ebraver@iihs.org;

sferguson@iihs.org).
Using a wide range of statistical methods, many studies have reported that motor vehicle occupants are at lower risk of non-fatal injury or death when riding in the rear seats of passenger vehicles in crashes. ${ }^{1-10}$ The protective effects of rear seating positions have been observed both for children and adults. ${ }^{38}$

The reduction in risk of dying related to rear seating positions has been reported as $26 \%$ by several studies using similar methods. ${ }^{348}$ Rear center positions appear to provide greater protection than rear outboard positions: One study reported that unrestrained adult rear center occupants had a $15 \%$ reduction in mortality risk compared with unrestrained rear outboard occupants. ${ }^{3}$ Rear seats are beneficial in frontal crashes but double the risk of dying in rear end crashes. $^{3}$

Combined effects of restraint use and seating position

Some studies have reported that restrained rear seat passengers are at lower risk of injuries and death than occupants restrained in front seats. ${ }^{14-7}$ Other researchers have concluded that rear seating does not provide superior occupant protection when front seat occupants are restrained. ${ }^{3}{ }^{11-13}$ One study included only injured children who had been transported to hospitals and reported that neither injury frequency nor severity were influenced by seating position among children aged 5 and younger using forward facing child restraints. ${ }^{13} \mathrm{~A}$ subsequent study that used similar data sources and included uninjured child occupants did report a protective effect of rear seating. ${ }^{10}$

Another question related to seating position is whether a child is safer using a lap/shoulder belt in the front seat than using only a lap belt in the rear. Lap and shoulder belts in the rear outboard seats of passenger cars sold in the United States were mandated starting in model year 1990 (54 FR 25275) and in light trucks, passenger vans, and utility vehicles starting in model year 1992 (54 FR 46257). Many manufacturers, including General Motors, Ford, and Honda, voluntarily equipped passenger cars with rear seat shoulder belts by model year $1988 .{ }^{14}$ Vehicles predating model year 1990 without lap/shoulder belts in rear seats continue to be driven by parents in the United States and other countries. Lap belts are more likely than lap/shoulder belts to result in injuries to the abdomen or spine, commonly known as seat belt syndrome. ${ }^{15}$

Combined effects of passenger airbags and seating position

Airbags have become increasingly common equipment in passenger vehicles, particularly in the United States, the United Kingdom, and Germany ( $R$ Lowne, personal communication, March 1998). ${ }^{16}$ Designed to protect occupants 
in frontal crashes, airbags inflate milliseconds after a crash is detected to form a cushion that protects the body from the hard interior structures of a vehicle as it decelerates. ${ }^{17}{ }^{18}$ Through 1996, about 27 million vehicles had both driver and passenger (dual) airbags in the United States. ${ }^{16}$ Dual airbags are required in all American passenger cars manufactured after 1 September 1997 and in all light trucks manufactured after 1 September 1998 (58 FR 46551). Neither driver nor passenger airbags are required in European vehicles (W Hollowell, personal communication, March 1998).

Right front passengers older than age 12 have a significantly lower risk of dying in frontal collisions when they are in vehicles equipped with passenger airbags. ${ }^{18}{ }^{19}$ However, passenger airbags pose a substantial risk of death and serious injury to infants and children riding as front seat passengers. ${ }^{20}$ Occupants at highest risk of airbag related injuries are those who are very close to inflating airbags, particularly infants riding in front seats in rear facing restraints, which position infants' heads close to airbag modules. Also at risk are unbelted or improperly belted children riding in front passenger seats, who can move forward during preimpact braking. ${ }^{20}$ No studies have compared the effects of children's seating positions in vehicles with and without passenger airbags.

This study should help to inform the debate on how best to protect children traveling in motor vehicles. The overall effects of seating position, the potential benefits of rear seating for restrained occupants, the comparative risks of traveling in rear seats using only lap belts versus front seats using lap/shoulder belts, and the combined effects of seating position and passenger airbags were examined. Recent American fatality data were used to estimate the relative risks of dying among children involved in fatal crashes for different seating positions by age, airbag status, restraint use, restraint type, and vehicle impact location.

\section{Methods}

Deaths were studied among 26233 children younger than age 13 who were passengers in motor vehicles involved in fatal crashes during 1988-95. Fatal crashes were identified using the National Highway Traffic Safety Administration's Fatality Analysis Reporting System (FARS) ${ }^{21}$ FARS is a census of police reported fatal crashes that occur on public roads in the United States in which the fatality occurs within 30 days of the crash; about 37000 fatal crashes occur each year. The main analysis was restricted to model year 1981-96 passenger cars, utility vehicles, and passenger minivans in fatal crashes involving single or multiple motor vehicles, including rollovers. Crashes in which the only fatality was a pedestrian or pedal cyclist were excluded, as were collisions with railroad trains or animals and non-rollover events that did not involve collisions (for example, immersions).

All child passengers of a motor vehicle in transport were selected for inclusion in the study if they were riding in either the front, second, third, or fourth row of seats, whether or not their exact position on the seat was known. Rear seating was defined as the second, third, or fourth row of seats.

Risk of death was compared among child passengers in front and rear seats and among those in rear outboard and rear center seats. The effects of seating position were examined within each category of the variables of interest, such as restraint use.

Analyses by airbag status included model years 1990-96, when airbags in non-luxury vehicles became more common, during calendar years 1990-96. Restricting the model years to 1990-96 lessened the age differences among newer vehicles equipped with passenger airbags and older vehicles not so equipped. In addition to comparisons of front and rear seat mortality risk, risk was compared among children traveling in front seats in vehicles with and without passenger airbags.

Child passengers were classified as restrained if they were reported to have used a restraint system, including shoulder belts only, lap belts only, lap/shoulder belts, forward or rear facing child safety seats, booster seats, or some restraint that was not further specified. Child passengers were classified as not restrained if they were reported as not using restraints ( $n=10671)$, as improperly belted ( $n$ $=41$ ), or as improperly using child safety seats $(n=70)$.

Shoulder belts were not required equipment in the rear seats of passenger cars until model year 1990 and were relatively rare during model years 1981-87. The effects of lap/ shoulder belt use in front and rear seats were examined among children aged 5-12 in model year 1990-96 passenger cars. Among children aged 5-12 in model year 1981-87 passenger cars, lap/shoulder belt users in front seats were compared with rear seat occupants using only lap belts.

The availability of an airbag system for the driver and front seat passenger were determined by using the VINDICATOR program to decode the vehicle identification numbers. ${ }^{22}$ Vehicle impact location was defined by the principal impact point (see fig 1). Impacts in

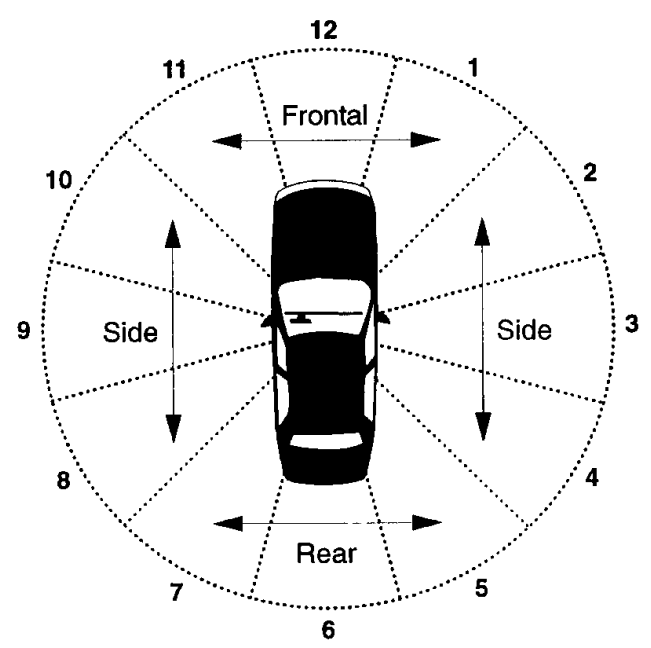

Figure 1 Clock positions for points of impact. 
Table 1 Relative risks of dying in a fatal crash by seat position for selected variables, model years 1981-96; FARS, 1988-95

\begin{tabular}{|c|c|c|c|c|c|c|c|}
\hline Variable & $\begin{array}{l}\text { Front passenger } \\
\text { deaths }\end{array}$ & $\begin{array}{l}\text { Total front } \\
\text { passengers }\end{array}$ & $\begin{array}{l}\text { Rear passenger } \\
\text { deaths }\end{array}$ & $\begin{array}{l}\text { Total rear } \\
\text { passengers }\end{array}$ & $\begin{array}{l}\text { Front-to-rear } \\
\text { seat relative risk }\end{array}$ & $95 \% C I$ & $\begin{array}{l}\text { Per cent change } \\
\text { in risk (rear seat) }\end{array}$ \\
\hline \multicolumn{8}{|l|}{ Age groups } \\
\hline$\leqslant 12$ & 2298 & 7962 & 3373 & 18271 & 1.56 & 1.49 to 1.64 & -36 \\
\hline $13+$ & 30600 & 74218 & 10585 & 37591 & 1.46 & 1.44 to 1.49 & -32 \\
\hline \multicolumn{8}{|l|}{ Age categories $\leqslant 12$} \\
\hline 0 & 359 & 787 & 357 & 1200 & 1.53 & 1.37 to 1.72 & -35 \\
\hline $1-4$ & 820 & 2666 & 1226 & 6784 & 1.70 & 1.58 to 1.84 & -41 \\
\hline $5-12$ & 1119 & 4509 & 1790 & 10287 & 1.43 & 1.34 to 1.52 & -30 \\
\hline \multicolumn{8}{|l|}{ Reported restraint use, age $\leqslant 12$} \\
\hline Not used & 1201 & 3102 & 1874 & 7680 & 1.59 & 1.50 to 1.68 & -37 \\
\hline Used & 970 & 4431 & 1277 & 9418 & 1.61 & 1.50 to 1.74 & -38 \\
\hline \multicolumn{8}{|l|}{ Vehicle impact location, age $\leqslant 12$} \\
\hline Front $(11,12,1$ clock positions) & 1097 & 4489 & 1247 & 9611 & 1.88 & 1.75 to 2.03 & -47 \\
\hline Side $(2,3,4,8,9,10$ clock positions) & 861 & 2205 & 1336 & 5059 & 1.48 & 1.38 to 1.59 & -32 \\
\hline Rear $(5,6,7$ clock positions $)$ & 75 & 486 & 361 & 1457 & 0.62 & 0.50 to 0.78 & +61 \\
\hline Rollover & 161 & 496 & 265 & 1429 & 1.75 & 1.48 to 2.07 & -43 \\
\hline
\end{tabular}

the 11,12 , and 1 clock positions were considered frontal impacts; impacts at 2, 3, 4, 8,9 , or 10 clock positions were considered side impacts; impacts at 5,6 , or 7 clock positions were considered rear impacts. Fatal crashes in which the most harmful events were rollovers were analyzed separately.

Mortality rates were computed for front and rear seated passengers (drivers were excluded). The relative risks and their 95\% confidence intervals (CIs) were estimated for fatal injuries by seating position. ${ }^{23}$ Based on the relative risk estimates, percentage changes in risk associated with rear seating positions were calculated. SAS version 6.10 and JMP version 3.1 for personal computers were used for data analyses. ${ }^{24} 25$

Using logistic regression, the effect of seating position was examined while controlling simultaneously for the effects of other variables affecting the risk of death, including age, restraint use, airbag status, vehicle impact location, vehicle size, and speed limit (a proxy for speed of travel). The odds ratios for death in rear seat positions were compared with each other before and after controlling for these potential confounding variables. Specific formulas for relative risks, $95 \%$ CIs for relative risk estimates, percentage changes in risk, and odds ratios are given below.

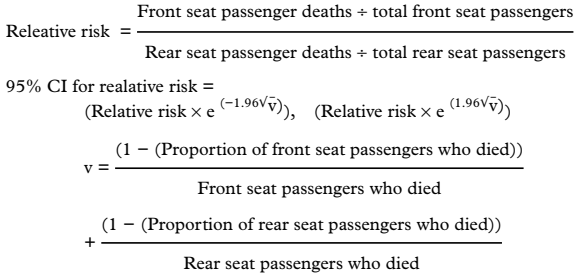

\section{Results}

Of the 26233 children involved in fatal crashes during 1988-95, 7962 were front seat occupants, of whom 2298 died, and 18271 were rear seat occupants, of whom 3373 died. A $36 \%$ reduction $(95 \% \mathrm{CI}=33,39 \%)$ in the risk of fatal injury was observed for rear seat child passengers aged 12 or younger compared with front seat child passengers (table 1). For occupants aged 13 and older, the reduction was similar: $32 \%$. Children of 1-4 years appeared to have the greatest benefit from rear seating, with a reduction in risk of $41 \%(95 \% \mathrm{CI}=37 \%$ to $46 \%$ ). Children aged 5-12 had a $30 \%$ reduced risk when seated in the rear.

Rear seating was most protective in frontal impacts and rollovers $(47 \%$ and $43 \%$ reductions in risk, respectively) but also was protective in side impacts ( $32 \%$ reduction in risk). The protective effect of rear seating for side impacts decreased by $9 \%$ after excluding impacts at clock positions 10 and 2, which can be frontal in direction. Children in rear seats were at a significant disadvantage in rear impact crashes: their risk of a fatal injury was $61 \%$ higher than that of children in front seats (table 1).

Restrained children in rear seats had the lowest death rates in fatal crashes-14\% compared with $39 \%$ among unrestrained children in front seats, $24 \%$ among unrestrained children in rear seats, and $22 \%$ among restrained children in front seats (table 1). Child occupants reported as using restraints in rear seats had a $38 \%$ reduction in risk of dying compared with front seat restraint users. A similar reduced risk (37\%) was observed among children reported as not using restraints in rear seats compared with non-users of restraints in front seats. The overall 36\% reduction in risk related to rear seating included children for whom restraint use was unknown.

Rear seating was associated with reduced mortality risk among restrained and unrestrained children in vehicles with and without passenger airbags (table 2). Vehicles without driver or passenger airbags had a $35 \%$ reduction in overall mortality risk among child occupants in rear seats. Risk of dying was $46 \%$ lower among children in the rear seats of vehicles equipped with passenger airbags and $31 \%$ lower among those in the rear seats of vehicles equipped only with driver airbags. Significant decreases in fatality risk were observed among rear seated children using lap/shoulder belts, child seats, and no restraints in vehicles with and without passenger airbags. 
Table 2 Relative risks of dying in a fatal crash by seat position for airbag and restraint status, model years 1990-96; FARS, 1990-96

\begin{tabular}{|c|c|c|c|c|c|c|c|}
\hline Variable & $\begin{array}{l}\text { Front passenger } \\
\text { deaths }\end{array}$ & $\begin{array}{l}\text { Total front } \\
\text { passengers }\end{array}$ & $\begin{array}{l}\text { Rear passenger } \\
\text { deaths }\end{array}$ & $\begin{array}{l}\text { Total rear } \\
\text { passengers }\end{array}$ & $\begin{array}{l}\text { Front-to-rear } \\
\text { seat relative risk }\end{array}$ & $95 \% C I$ & $\begin{array}{l}\text { Per cent change } \\
\text { in risk (rear seat) }\end{array}$ \\
\hline \multicolumn{8}{|l|}{ Airbag status, age $\leqslant 12$} \\
\hline Dual airbags & 104 & 347 & 151 & 939 & 1.86 & 1.50 to 2.32 & -46 \\
\hline Driver airbag only & 160 & 655 & 302 & 1800 & 1.46 & 1.23 to 1.72 & -31 \\
\hline No airbags in vehicle & 386 & 1417 & 639 & 3625 & 1.55 & 1.38 to 1.73 & -35 \\
\hline \multicolumn{8}{|c|}{ Reported restraint use be airbag status, age $\leqslant 12$} \\
\hline \multicolumn{8}{|c|}{ No airbags } \\
\hline None & 146 & 371 & 295 & 1183 & 1.58 & 1.34 to 1.85 & -37 \\
\hline Lap/shoulder belt & 112 & 584 & 76 & 543 & 1.37 & 1.05 to 1.79 & -27 \\
\hline Child seat & 47 & 181 & 122 & 837 & 1.78 & 1.33 to 2.39 & -44 \\
\hline \multicolumn{8}{|l|}{ Driver airbag only } \\
\hline None & 65 & 171 & 143 & 560 & 1.49 & 1.17 to 1.89 & -33 \\
\hline Lap/shoulder belt & 49 & 261 & 36 & 342 & 1.78 & 1.20 to 2.66 & -44 \\
\hline Child seat & 17 & 91 & 55 & 365 & 1.24 & 0.76 to 2.03 & -19 \\
\hline \multicolumn{8}{|l|}{ Dual airbags } \\
\hline None & 48 & 83 & 75 & 276 & 2.13 & 1.63 to 2.78 & -53 \\
\hline Lap/shoulder belt & 27 & 150 & 13 & 206 & 2.85 & 1.52 to 5.34 & -65 \\
\hline Child seat & 11 & 39 & 27 & 227 & 2.37 & 1.28 to 4.38 & -58 \\
\hline
\end{tabular}

Table 3 Effects of rear seating positions and type of belt used, all impact directions; FARS, 1988-95

\begin{tabular}{|c|c|c|c|c|c|}
\hline Seat positions and restraint use & $\begin{array}{l}\text { Children } \\
\text { who died }\end{array}$ & $\begin{array}{l}\text { Children } \\
\text { involved in } \\
\text { fatal crashes }\end{array}$ & $\begin{array}{l}\text { Relative } \\
\text { risk }\end{array}$ & $95 \% C I$ & $\begin{array}{l}\text { Per cent change } \\
\text { in risk for rear } \\
\text { seat or centre rear } \\
\text { seat occupants }\end{array}$ \\
\hline \multicolumn{6}{|l|}{ Age $0-12$, all eligible model years } \\
\hline Rear outboard seat, all & 2484 & 13155 & 1.1 & 1.02 to 1.19 & -9 \\
\hline Rear center seat, all & 700 & 4083 & & & \\
\hline Rear outboard seat, any type of restraint & 1053 & 7377 & 1.31 & 1.14 to 1.52 & -24 \\
\hline Rear center seat, any type of restraint & 195 & 1794 & & & \\
\hline \multicolumn{6}{|l|}{ Age $5-12$, all eligible model years } \\
\hline Front seat, used lap/shoulder belt & 363 & 1835 & 0.90 & 0.81 to 1.00 & +11 \\
\hline Rear seat, no restraint & 1116 & 5088 & & & \\
\hline \multicolumn{6}{|c|}{ Age $5-12$, passenger cars only, model years $1990-96^{\star}$} \\
\hline Front seat, used lap/shoulder belt & 76 & 356 & 1.78 & 1.26 to 2.51 & -44 \\
\hline \multirow{2}{*}{\multicolumn{6}{|c|}{ Age $5-12$, passenger cars only, model years $1981-87^{\star}$}} \\
\hline & & & & & \\
\hline Front seat, used lap/shoulder belt & 177 & 765 & 1.46 & 1.21 to 1.76 & -32 \\
\hline Rear seat, used lap belt only & 174 & 1095 & & & \\
\hline
\end{tabular}

* Shoulder belts were not required equipment in passenger car rear seats until model year 1990. Many manufacturers equipped passenger cars with rear seat lap/shoulder belts by model years 1988 .

Within each of the restraint use categories, the relative risks of death associated with front seating relative to rear seating were higher for children in vehicles with dual airbags, ranging from 2.13 to 2.85 (table 2). Children in front seats of vehicles without passenger airbags had relative risks of death ranging from 1.24 to 1.78 .

Airbag effects also were assessed by comparing mortality among children in front seats. Among unrestrained children in front seats, a statistically significant increased risk of dying was observed among those traveling in vehicles with dual airbags relative to those in vehicles equipped only with driver airbags (relative risk = $1.52 ; 95 \% \mathrm{CI}=1.15$ to 2.01 ). A non-significant risk of similar magnitude was observed among front seated children in child seats in vehicles with dual airbags relative to those in vehicles with driver airbags only; the small numbers of such children may be responsible for the lack of statistical significance.

Table 3 shows that children aged 0-12 in rear center seats have a $9-24 \%$ lower risk of dying when involved in fatal crashes than child occupants of rear outboard seats. Among children 5-12, the mortality risk among nonusers of restraints in rear seat positions was $11 \%$ higher $(95 \% \mathrm{CI}=0 \%$ to $23 \%)$ than that of front seat occupants using lap/shoulder belts. Among children aged 5-12 in model year 1990-96 passenger cars, lap/shoulder belt users in rear seats had a $44 \%$ lower risk of dying compared with lap/shoulder belt users in front seats. A reduction in risk (32\%) also was observed among rear seated children aged 5-12 using only lap belts compared with front seated children using lap/shoulder belts in model year 1981-87 passenger cars.

The protective effects of seating position remained after adjustment for other potential confounding variables affecting crash mortality risk. The crude odds ratio for dying in a rear seating position was $0.56(95 \% \mathrm{CI}=0.52$ to 0.59 ), and the adjusted odds ratio was 0.53 ( $95 \% \mathrm{CI}=0.5$ to 0.57 ). The multivariate odds ratios for other variables were in the expected directions, indicating that younger ages (less than 5 years), non-use of restraints, side impacts, small vehicles, and high speed limits (55-75 $\mathrm{mph}$ ) were associated with significantly increased mortality risk. Maximum likelihood tests for goodness of fit indicated significant improvement from baseline for the multivariate $\operatorname{model}\left(\chi^{2}=1913,13 \mathrm{df} ; \mathrm{p}<0.0001\right)$.

\section{Discussion}

Children were at significantly lower risk of dying in rear seats of passenger vehicles whether or not these vehicles were equipped with passenger airbags. The reduction in risk was greater among rear seated children in vehicles with passenger airbags. 
As expected, rear seat positions were most protective in frontal collisions. The one crash circumstance in which rear seats placed children at increased risk of death was when vehicles were struck in the rear. However, relatively few passenger cars involved in fatal collisions are struck in rear locations (5\%) compared with front (62\%) and side (25\%) impact locations. ${ }^{26}$

The protective effects observed for rear seating in side impacts are not readily explicable. These protective effects diminished but were still present when side collisions with a potential frontal component (10 and 2 clock positions) were removed from the group of side impact collisions.

The benefit of rear seating was present-and of the same magnitude-whether or not children were using restraints. Significant benefits from rear seat positions also were observed for children aged 5-12 using only lap belts in rear seats compared with children using lap/shoulder belts in front seats. Therefore, the benefits of using lap belts in the rear seat in fatal crashes appear to outweigh the increased risks of seat belt syndrome.

The rear seat was no longer advantageous when front seated lap/shoulder belt users aged 5-12 were compared with rear seated children traveling unrestrained, which is consistent with other studies. ${ }^{1727}$ However, because past research has shown that unrestrained occupants are involved in a higher proportion of severe crashes, ${ }^{28}{ }^{29}$ the restrained and unrestrained child occupants in this study may not necessarily have been exposed to similar crash forces. In addition, any FARS based analysis comparing restrained and unrestrained occupants should be interpreted cautiously because police officers frequently misclassify restraint use. ${ }^{30}$

Misclassified restraint use is not a major limitation for the other analyses because estimating the combined effects of seating positions and restraint use involved comparisons of seating position risk within the same restraint use categories. Yet there are other limitations of FARS data that may affect the findings from this study. One is that the true population at risk of involvement in fatal crashes is undercounted because there is no method of identifying non-fatal crashes that would have been fatal if one or more occupants had not been seated in the rear seat.

Another concern is that there may be confounding effects from other variables that could not be addressed by the data analysis. If vehicles carrying children in rear seats tend to have lower risk drivers and travel under more favorable conditions than vehicles carrying children in front seats, then the protectiveness of rear seats could be overestimated by this study.

In spite of the limitations discussed above, this study provides strong and consistent evidence that rear seat occupancy is associated with a significant reduction in fatality risk. Multivariate analyses that adjusted for potential confounding factors (for example, vehicle size) continued to find protective effects for rear seating positions.

\section{Implications for prevention}

Parents and other care providers should be strongly encouraged to place infants and children in rear seats, whether or not vehicles are equipped with airbags. Rear seat travel reduces child passengers' risk of death in severe frontal collisions and rollovers and eliminates injuries from deploying passenger airbags. Increasing the proportion of children who use restraints also will reduce the occurrence of fatal and non-fatal injuries to children. ${ }^{8}$ Most of the children who have been fatally injured by airbags have been either unbelted or improperly belted. ${ }^{20}$ Whether seated in the front or rear, restrained children are less likely to be injured or killed than children who are unrestrained. ${ }^{14-6}$

A 1997 study found that fewer than $15 \%$ of children in Frankfurt, Brussels, and Paris travel in front seats, although rear seating is no longer mandatory in Germany, Belgium, and France. ${ }^{31}$ Higher percentages of children in the United States ride in front seats, including 30\% of those involved in fatal crashes (table 1) and $37 \%$ of those involved in towaway crashes during $1988-95 .^{32}$ Other studies have observed the following percentages in front seats: $50 \%$ of rear facing restraints in vehicles without passenger airbags, $7 \%$ of rear facing restraints in vehicles with passenger airbags, $40 \%$ of preschool children, and $60 \%$ of elementary schoolchildren..$^{33}$ Unrestrained drivers, who are less likely to restrain children, and trips with a child as the sole passenger are associated with higher proportions of children in front seats. ${ }^{32}$

Industry, government, and safety groups are attempting to educate parents about the need for children to travel restrained in rear seats. ${ }^{35} 36$ However, education alone may not be effective in getting parents to move infants and children to rear seats. A survey in the United States reported that $75 \%$ of people who transport infants and children in vehicles with passenger airbags said they were aware of the dangers of passenger airbags, ${ }^{37}{ }^{38}$ yet $76 \%$ said they sometimes transport children aged 5-9 in front seats (S A Ferguson, unpublished data). One American demonstration program was able to increase child restraint use but was not able to increase the proportion of children traveling in rear seats. $^{34}$

Only Luxembourg bans infants in rear facing restraints from front seats of vehicles with passenger airbags. ${ }^{39}$ Belgium, France, Ireland, Luxembourg, Portugal, and Spain require that children of particular ages be seated in the rear if they are not using restraints. ${ }^{39}$ Australia requires top tether straps for restraints designed for infants weighing less than $9 \mathrm{~kg}$, which in effect is a requirement for infants to be seated in the rear. ${ }^{40}$

In the United States, Rhode Island requires children aged 5 and younger and Louisiana requires children 3-12 to sit restrained in the rear, unless the vehicles lack rear seats or the available rear seat positions have been filled by other children. ${ }^{41}$ Other states (Connecticut, Delaware, Illinois, Massachusetts, New Jersey, New York, Pennsylvania, Tennessee) now are 
considering such legislation. ${ }^{42}{ }^{43}$ The United States National Highway Traffic Safety Administration has proposed requiring two rear seating positions in passenger vehicles to be equipped with specially designated anchorages for securing child restraints (62 FR 7858). This requirement probably would result in more parents placing young children in rear seats.

In Europe, restraint use is required in all seating positions; however, rear seat restraint use rates continue to be lower than front seat use rates. ${ }^{44}$ In the United States, all states now require the use of restraints for children aged $0-3$; however, fewer than half the states require that all children younger than 16 use restraints in all seating positions. ${ }^{41}$ Consequently, rates of restraint use are lower for children aged 5-12 than for younger children in the United States. ${ }^{6}$ All countries should have laws requiring children and teenagers to use restraints whenever and wherever they sit in motor vehicles and should actively enforce those laws.

Legislators throughout the world need to weigh the advantages and disadvantages of any potential laws to mandate rear seating for children. There are a few medical or behavioral circumstances when front seats may be appropriate for children. Another consideration is the resource constraints of governments that are not consistently enforcing current child restraint use laws. Strengthening the existing laws requiring restraint use for children and enforcement of those laws may be a more cost effective use of public safety resources.

Belt use laws in too many jurisdictions allow police to issue citations for failure to use seat belts only if they have some other reason for stopping a particular vehicle. ${ }^{41}$ Based on past research, allowing police to stop vehicles solely for non-use of belts and stepped up enforcement of restraint use laws should succeed in increasing the proportion of children that are properly restrained. ${ }^{45-49}$

This work was supported by the Insurance Institute for Highway Safety. The authors would like to thank Alice Whitfield and Amy Feldman for their able assistance with computer analyses. Portions of this paper were presented at the Second Child Occupan Protection Symposium on 12 November 1997 (special session Protection Symposium on 12 November 1997 (special session of the 41st Stapp Car Conference, 41st annual AAAM confer(1997, Society Of Automotive Engineers Inc).

1 Williams AF, Zador P. Injuries to children in automobiles in relation to seating location and restraint use. Accid Anal relation to seating
Prev 1977;9:69-76.

2 Prev 1977;9:69-76. passenger in frontal crashes. Proceedings of the 22nd Conference of the American Association for Automotive Medicine. Morton Grove, IL: AAAM, 1978.

3 Evans L, Frick MC. Seating position in cars and fatality risk. Am F Public Health 1988;78:1456-8.

4 Partyka SC. Lives saved by child restraints from 1982 through 1987. Washington, DC: National Highway Traffic Safety Administration, 1988

5 Agran P, Castillo D, Winn D. Comparison of motor vehicle occupant injuries in restrained and unrestrained 4-14 year olds. Accid Anal Prev 1992;24:349-55.

6 Johnston C, Rivara F, Soderberg R. Children in car crashes: analysis of data for injury and use of restraints. Pediatrics 1994;93:960-5.

7 Huelke D, Compton CP. The effects of seat belts on injury severity of front and rear seat occupants in the same frontal severity of front and rear seat occupants
crash. Accid Anal Prev 1995;27:835-8.

8 National Highway Traffic Safety Administration. Revised estimates of child restraint effectiveness. Washington, DC: US estimates of child restraint effectiveness.
9 National Transportation Safety Board. The performance and use of child restraint systems, seatbelts, and air bags for children in passenger vehicles. (NTSB/SS-9601.) Washington, DC: National Transportation Safety Board, 1996.

10 Walsh M, Kelleher-Walsh B, McCullough C. A study of motor vehicle accidents involving children. (962436.) Proceedings of the 40th Stapp Car Crash Conference. Warrendale, PA: Society of Automotive Engineers, 1996:357-70.

11 Norin H, Carlsson G, Korner J. Seat belt usage in Sweden and its injury reducing effect. (Paper 840194.) Advances in belt restraint systems: design, performance, and usage. Warrendale, PA: Society of Automotive Engineers, 1984:15-28.

12 Krafft M, Nygren C, Tingvall C. Rear seat occupant protection. A study of children and adults in the rear seat of cars tion. A study of children and adults in the rear seat of cars
in relation to restraint use and car characteristics. $\mathcal{F}$ Traffic in relation to restraint

13 Kelleher-Walsh B, Walsh M, States J, et al. Trauma to children in forward-facing car seats. (SAE technical paper 933095.) Warrendale, PA: Society of Automotive Engineers, 1993.

14 Insurance Institute for Highway Safety. 1988 cars with standard rear seat shoulder belts. Status Report 1988;23:7.

5 Lane JC. The seat belt syndrome in children. Accid Anal Prev 1994;26:813-20.

16 National Highway Traffic Safety Administration. Federal motor vehicle safety standards; occupant crash protection. Notice of proposed rulemaking. Federal Register 1996;62: 807-31.

17 Ferguson SA. Update on airbag performance in the United States: benefits and problems. Airbag 2000: 3rd International Symposium on Sophisticated Car Occupant Systems. Karlsruhe, Germany: Fraunhofer-Institut Fur Chemische Technologie (ICT), 1996;7:1-17.

18 Kahane CJ. Fatality reduction by air bags: analyses of accident data through early 1996. (DOT-HS-808-470.) Washington, DC: National Highway Traffic Safety Administration, 1996.

19 Braver ER, Ferguson SA, Greene MA, et al. Reductions in deaths in frontal crashes among right front passengers in vehicles equipped with passenger airbags. $\mathscr{f} A M A 1997 ; 278$ : 1437-9.

20 National Highway Traffic Safety Administration. Special crash investigation report. Washington, DC: US Department crash investigation report.
of Transportation, 1997.

21 National Highway Traffic Safety Administration. Fatality analysis reporting system (formerly fatal accident reporting system). Washington, DC: National Highway Traffic Safety Administration, 1988-95.

22 Highway Loss Data Institute. VINDICATOR 96. Versions 96.3 and 96.4. Arlington, VA: Highway Loss Data Institute, 1996.

23 Kleinbaum DG, Kupper LL, Morgenstern H. Epidemiologic research: principles and quantitative methods. London: Wadsworth, 1982 .

24 SAS Institute. SAS. Version 6.10. Cary, NC: SAS Institute, 1993.

25 SAS Institute. $7 M P$ statistical software. Version 3.1. Cary, NC: SAS Institute, 1994

26 National Highway Traffic Safety Administration. Traffic safety facts 1995. (DOT-HS-808-471.) Washington, DC: US Department of Transportation, 1996.

27 Lowne R, Roberts A, Toy P, et al. The effect of the UK seat belt legislation on restraint usage by children. (840526.) Advances in belt restraint systems: design, performance, and usage. Warrendale, PA: Society of Automotive Engineers, 1984:369-80.

28 Campbell BJ. Safety belt injury reduction related to crash severity and front seated position. $\mathcal{F}$ Trauma 1987;27:7339.

29 Ricci LL, ed. NCSS statistics: passenger cars. (Report UM-HSRI-80-36.) Ann Arbor, MI: Highway Safety Research Institute, University of Michigan, June 1980.

30 Greenberg L. Police accident report quality assessment project. (DOT-HS-808-487.) Washington, DC: National Highway Traffic Safety Administration, 1996.

31 Graham JD, Goldie SJ, Segui-Gomez M, et al. Reducing risks to children in vehicles with passenger airbags. Pediatrics Online (in press).

32 Edwards J, Sullivan K. Where are all the children seated and when are they restrained? (SAE technical paper series 971550.) Warrendale, PA: SAE International, 1997:1-8.

33 Salaita K. Observation of infant restraint use and seating locations. Arlington, VA: Insurance Institute for Highway Safety, 1995.

34 Williams AF, Wells JK, Ferguson SA. Development and Wiliams AF, Wells JK, Ferguson SA. Development and evaluation of programs to increase
use. $\mathcal{F}$ Safety Res $1997 ; 28: 197-202$.

35 Hans M. Coalition deploys air-bag campaign. Traffic Safety 1996;96:26-7.

36 Insurance Institute for Highway Safety. Kids and airbags. (Videotape and pamphlet.) Arlington, VA: Institute for Highway Safety, 1996

37 Ferguson SA, Williams AF. Survey of parents of infants about rear facing child restraints. Arlington, VA: Insurance Institute for Highway Safety, 1996.

38 Insurance Institute for Highway Safety. Parents aware of airbag danger, know older kids should ride in rear seat, too. Status Report 1996;31:7.

39 Commission of the European Communities. Commission report on the implementation of directive 91/671/EEC of 16 December 1991 on the approximation of the laws of the member states relating to compulsory use of safety belts in vehicles of less states relating to compulsory use of safety belts in vehicles of less
than 3.5 tonnes. (COM(96) 244 final.) Brussels: Commission of the European Communities, 1996. 
40 Lumley M. Tether straps for child restraints-the Australian experience and recommendations. Presentation at National Highway Traffic Safety Administration workshop, 10 October 1996. Washington, DC: National Highway Traffic Safety Administration, 1996.

41 Insurance Institute for Highway Safety. State law facts: child restraint, belt laws. Arlington, VA: Institute for Highway Safety, 1996.

42 Incantalupo T. Get in the back, kids. Newsday 13 February 1997.

43 Safe Ride News. Legislation and enforcement move into high gear. Safe Ride News 1997;16:1-4.

44 European Transport Safety Council. Seat belts and child restraints: increasing use and optimising performance. Brussels: ETSC, 1996.
45 Ulmer RG, Preusser CW, Preusser DF. Evaluation of California's safety belt law change to primary enforcement. Washington, DC: National Highway Traffic Safety Administration, 1994.

46 Lund AK, Stuster J, Fleming A. Special publicity and enforcement of California's belt use law: making a "secondary" law work. fournal of Criminal fustice 1989;17: 329-41.

47 Wells JK, Preusser D, Williams AF. Enforcing alcoholimpaired driving and seat belt use laws in Binghamton, New York. F Safety Res 1992;23:63-71.

48 Williams AF, Lund AK, Preusser DF, et al. Results of a seat belt use law enforcement and publicity campaign in Elmira, New York. Accid Anal Prev 1987;19:243-9.

49 Williams AF, Reinfurt D, Wells JK. Increasing seat belt use in North Carolina. F Safety Res 1996;27:33-41.

\section{Editorial Board Member: brief biography}

\section{RICHARD STANWICK}

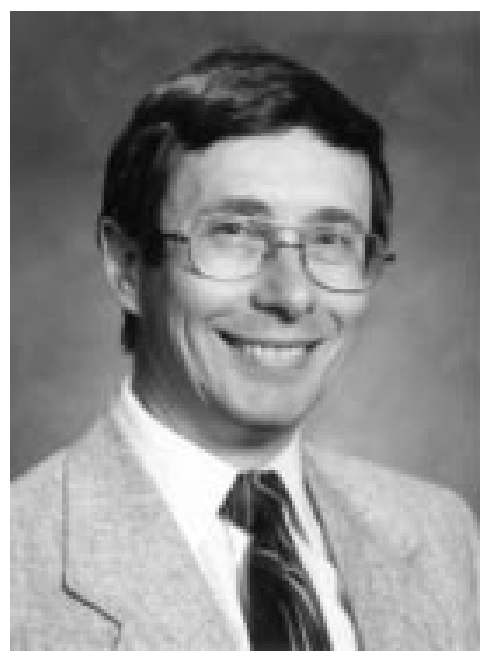

Dr Richard Stanwick is currently the Regional Medical Health Officer and Director of Clinical Information for the Capital Health Region in Victoria. $\mathrm{He}$ was born in Winnipeg, Manitoba. He completed his medical school training and received his fellowship in paediatrics after training at the Winnipeg Children's Hospital. He did a fellowship in community paediatrics at McGill University, where he also received his masters degree in epidemiology and health. On his return to Manitoba, Dr Stanwick acquired his fellowship in community medicine and rose to the rank of Full Professor at the University of Manitoba. He spent two years with the Province of Manitoba, including one as the Acting Provincial Epidemiologist. He became the Medical Officer of Health for the City of Winnipeg in 1990, a post he held for five years. He joined the Capital Regional District in September 1995 and the Capital Health Region in April 1997.

Dr Stanwick has done considerable research in the area of injury control, particularly in the area of burn prevention and advocacy. He has been recognised by the Canadian Public Health Association in July with an Honorary Life Membership for his contributions to public health, and in particular injury prevention. 